\title{
Pelagic oxycline and damage potential of hypoxia to the Pacific oyster Crassostrea gigas suspended in longline aquaculture systems
}

\author{
Sang Jun Lee' ${ }^{1}$, Qtae Jo ${ }^{1, *}$, Jong-Cheol Han ${ }^{2}$, Yeong-Cheol Park ${ }^{3}$, Tae Gyu Park ${ }^{4}$ \\ ${ }^{1}$ Shellfish Aquaculture Lab, South Sea Fisheries Research Institute, NIFS, Jeonnam 59780, South Korea \\ ${ }^{2}$ Shellfish Hatchery Center, Southeast Sea Fisheries Research Institute, NIFS, Gyeognam 52440, South Korea \\ ${ }^{3}$ Environmental Analysis Lab, Southeast Sea Fisheries Research Institute, NIFS, Gyeognam 53085, South Korea \\ ${ }^{4}$ Harmful Algal Bloom Lab, Southeast Sea Fisheries Research Institute, NIFS, Gyeognam 53085, South Korea
}

\begin{abstract}
Depletion in dissolved oxygen (DO) occurred in 2 semi-enclosed shallow bays in Korea in which Crassostrea gigas were suspended for aquaculture. DO depletion started at the bottom and expanded rapidly upwards for days until it was blocked by a temperature-driven density differential. This resulted in the formation of pelagic oxyclines at a depth of $2-4 \mathrm{~m}$ in one bay (Hypoxic Site 1, HS-1) and 2-5 $\mathrm{m}$ in the other (Hypoxic Site 2, HS-2). Water above the oxycline was normoxic $\left(>4 \mathrm{mg} \mathrm{l}^{-1}\right)$, while water below the oxycline was hypoxic $\left(<1 \mathrm{mg} \mathrm{l}^{-1}\right)$. The oxyclines were accompanied by significant changes in environmental variables and phytoplankton composition, but these changes were not fatal to the oysters. However, the oxyclines themselves caused oyster mortality: complete mortality below the oxyclines and depth-dependent mortality within the oxycline. Interestingly, mortality was observed in a significant number of oysters above the oxyclines compared with the reference site, and greater mortality was observed in HS-1 than HS-2. These findings suggest the existence of toxic compounds that diffuse up from below the oxycline in shallow waters and exert effects that overshadow those of DO. The higher mortalities in the HS-1 normoxic layer supported this influence from the bottom layer. In a subsequent experiment, we observed additional mortalities among the surviving oysters in the upper normoxic waters after the bays had completely reoxygenated during fall turnover. These data provide useful observations of hypoxia in highly sheltered shallow waters and can be used to guide site selection for oyster longline aquaculture.
\end{abstract}

KEY WORDS: Oxycline $\cdot$ Sheltered shallow coast $\cdot$ Oyster farm $\cdot$ Damage

\section{INTRODUCTION}

Coastal hypoxia refers to a state in which oxygen supply is reduced to a level that becomes detrimental to marine organisms (Breitburg 2002). Because hypoxia is forecasted to increase in severity and extent as a result of anthropogenic nutrient enrichment (Diaz \& Rosenberg 2008) and global warming (Keeling et al. 2010, Altieri \& Gedan 2015), it has become a focal subject of coastal studies, which have revealed that damage due to hypoxia is more compli-

*Corresponding author: qtjo@korea.kr cated and concerning than previously thought. Diaz \& Rosenberg (1995) classified dissolved oxygen (DO) concentrations at or near $2 \mathrm{mg} \mathrm{l}^{-1}$ (approximately $30 \%$ air saturation) as hypoxic, providing a lethal threshold level for ecosystem damage. However, recent evidence has identified hypoxia-related damage to onset at higher DO concentrations than those of previous classifications (Gray et al. 2002, VaquerSunyer \& Duarte 2008, Steckbauer et al. 2011).

Shellfish are a good animal model for hypoxia studies because they are sessile organisms. Animal toler-

() The authors 2017. Open Access under Creative Commons by Attribution Licence. Use, distribution and reproduction are unrestricted. Authors and original publication must be credited. 
ance to hypoxic exposure is species-specific, and even habitat-specific within a given species, and shellfish are generally more resistant to low DO concentrations than are fish (Stickle et al. 1989, Wang \& Widdows 1991, Vaquer-Sunyer \& Duarte 2008, Ekau et al. 2010). Shellfish responses to low DO concentrations are also species-specific (Khan \& Ringwood 2016) but highly variable depending on habitat (Cancino et al. 2003, Wang et al. 2011, Gobler et al. 2014). However, much of this knowledge comes from a compilation of research performed under specific environmental conditions, which might not provide accurate representations of the occurrence of hypoxia in nature.

After China, South Korea leads the global aquaculture production of Pacific oysters Crassostrea gigas. In Korean waters, this species is principally cultured in longline systems, which are typically installed in semi-enclosed bays or along sheltered coasts for protection from extreme water motion during typhoon season. Oyster longline aquaculture systems in oxycline-established coastal waters could provide a natural laboratory with a realistic experimental design for hypoxia studies, particularly in highly sheltered shallow waters. In longline systems, suspended lines carrying oyster clutches stretch from the surface to almost the bottom of the water column. This system configuration allows oysters to be exposed to a DO gradient naturally generated by coastal oxyclines. However, studies examining such an approach have not been undertaken to date.

This study examined hypoxia under environmental conditions in highly sheltered shallow waters and its damage potential to oysters. At the beginning of August 2013, wide-scale DO depletion occurred from the bottom of the water column and expanded upwards along the southeast coast of Korea, resulting in a unique oxycline in 2 highly sheltered local bays, Goseong and Buksin, containing traditional commercial C. gigas longlines. Soon after the oxyclines were established, we evaluated the nature of the hypoxia and the damage potential to growing oysters exposed to the oxycline-associated gradients in DO and other environmental variables, both during the hypoxic period and after reoxygenation. The results of this study can be used to guide site selection for longline $C$. gigas aquaculture.

\section{MATERIALS AND METHODS}

\section{Study site and oyster longlines}

In August 2013, a large area of hypoxic water appeared in 2 highly sheltered local bays in Goseong and Buksin, Korea, where Crassostrea gigas were farmed in longline aquaculture systems. Study sites were established in the 2 hypoxic areas (Hypoxic Site 1 [HS-1] in Goseong Bay and Hypoxic Site 2 [HS-2] in Buksin Bay) and in one nearby area serving as a normoxic reference site (Fig. 1). The local governments performed monthly monitoring of environmental conditions at the longlines sites. Therefore, information on aquaculture management and ambient conditions was available by courtesy of the local governments.

\section{Environmental variables}

Temperature, DO, pH, and salinity were measured weekly in situ using a portable instrument (YSI-6000; YSI) at $1 \mathrm{~m}$ intervals to a depth of $8 \mathrm{~m}$, representing the extension of the suspended lines. Chemical oxygen demand (COD) and levels of nitrogenous compounds $\left(\mathrm{NH}_{4}-\mathrm{N}, \mathrm{NO}_{2}-\mathrm{N}\right.$, and $\left.\mathrm{NO}_{3}-\mathrm{N}\right)$, phosphate $\left(\mathrm{PO}_{4}-\mathrm{P}\right)$, and dissolved inorganic nitrogen (DIN) were measured both at the bottom of the water column and at the surface $(1 \mathrm{~m})$. Analytical procedures were performed according to the National Fisheries Research and Development Institute standards for chemical analysis (MOLIT 2010), which generally follow inter-

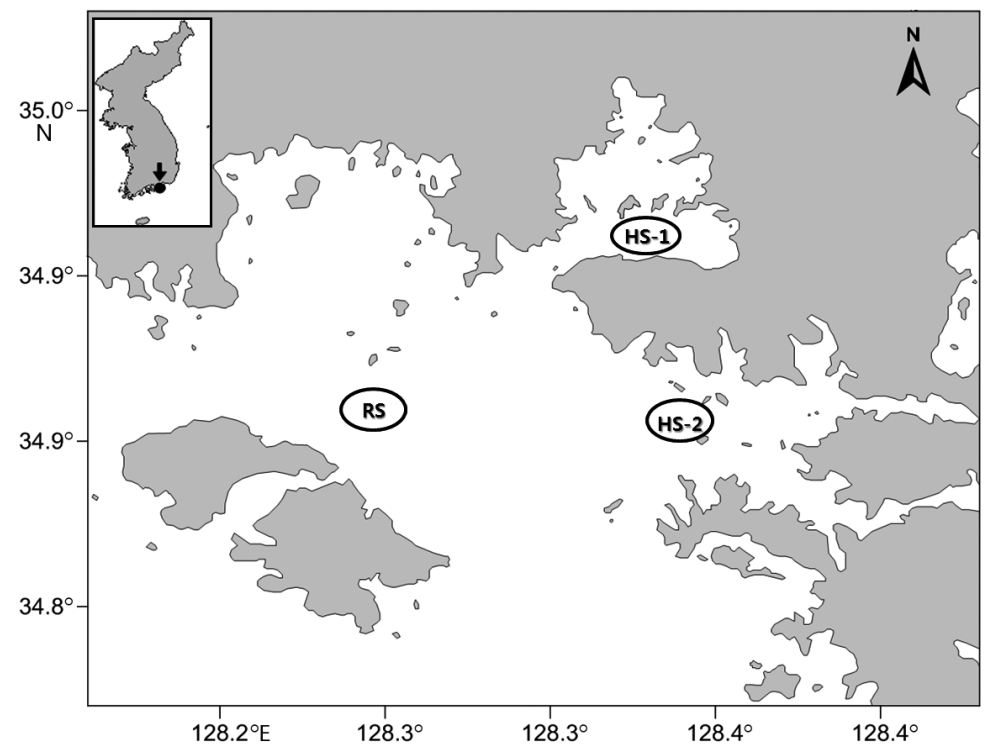

Fig. 1. Location of the study sites at the southern Korean coast. Two hypoxic sites (HS) in highly sheltered bays (HS-1 in Goseong Bay, HS-2 in Buksin Bay) and 1 normoxic reference site (RS) in a nearby area 
national standard methods for marine environmental analyses (Strickland \& Parsons 1972, Grasshoff et al. 1999). All measurements were taken weekly, in triplicate, from the early to late phase of the oxycline.

\section{Phytoplankton and chlorophyll a}

Surface water samples (1 l) were collected from each study site in 51 Niskin bottles. Both fresh and fixed water samples were prepared. Fresh water samples were concentrated to $3 \mathrm{ml}$ by sieving (mesh size: $10 \mu \mathrm{m}$ ) and analyzed within $2 \mathrm{~h}$ of sampling. Fixed samples containing $2 \%$ Lugol's solution (final concentration) were allowed to settle for at least $24 \mathrm{~h}$ and were then concentrated to a final volume of $20 \mathrm{ml}$ in graduated tubes. Phytoplankton species were identified under a light microscope (Eclipse 80i; Nikon). Chlorophyll a (chl a) was measured following the standard method (MOLIT 2010).

\section{Oysters and mortality}

According to local government data, the oysters growing at the study sites were cultured from wild seeds collected in September of the previous year and hardened for approximately 4 mo prior to suspension. Table 1 summarizes the longline system and oysters at HS-1, HS-2, and the reference site before the hypoxia event. For subsequent monitoring in our study, mortality was recorded in $1 \mathrm{~m}$ intervals and calculated onboard by subtracting cumulative live counts from the latest live counts measured by the local government before hypoxia. Detached oysters and apparently moribund individuals were included

Table 1. Longline system and Crassostrea gigas growth performance before hypoxia. On-growth data were measured 7 to $10 \mathrm{~d}$ before the hypoxia event; percentage survival (PS) and number of on-growing oysters on the clutch (NC2) were calculated based on number of seed oysters on the clutch (NC1), in which oysters detached from the collectors were considered to be dead. L: suspension line length; SI: suspension line interval on longline; CI: clutch interval on the suspension line; SL: shell length; IM: installation month; HWS: hardened wild seed; HS-1: Hypoxic Site 1 in Goseong Bay; HS-2: Hypoxic Site 2 in Buksin Bay; RS: reference site. Data courtesy of local governments:

HS-1 from Goseong County, HS-2, and RS from Tongyeong City, Korea

\begin{tabular}{|c|c|c|c|c|c|c|c|c|c|}
\hline \multirow[t]{2}{*}{ Site } & \multicolumn{3}{|c|}{ Longline system } & \multirow{2}{*}{ Type } & \multicolumn{3}{|c|}{ - Seed - } & \multicolumn{2}{|c|}{ On-growth } \\
\hline & $\begin{array}{c}\mathrm{L} \\
(\mathrm{m})\end{array}$ & $\begin{array}{c}\mathrm{SI} \\
(\mathrm{cm})\end{array}$ & $\begin{array}{c}\mathrm{CI} \\
(\mathrm{cm})\end{array}$ & & $\begin{array}{c}\mathrm{SL} \\
(\mathrm{mm})\end{array}$ & NC1 & IM & $\begin{array}{c}\mathrm{SL} \\
(\mathrm{mm})\end{array}$ & $\begin{array}{c}\text { PS } \\
\text { (NC2) }\end{array}$ \\
\hline HS-1 & $7.5-8.0$ & 45 & 20 & HWS & 52 & 23 & May & 68 & 69 (15) \\
\hline HS-2 & $6.5-7.5$ & 40 & 20 & HWS & 51 & 23 & May & 66 & 73 (18) \\
\hline $\mathrm{RS}$ & $7.5-8.5$ & 40 & 20 & HWS & 48 & 25 & Apr & 71 & $71(18)$ \\
\hline
\end{tabular}

in the mortality count (J. Han et al. 2013). Mortality at depth $n(\mathrm{~m})$ was determined as the sum of dead oysters along the length of the suspended lines at depths between $n$ and $n+1(\mathrm{~m})$. At the end of the hypoxic period, all surviving oysters above the oxycline were harvested and separated. Of these, 90 oysters were randomly selected and caged in oyster bags (Vexar oyster bag, approximately $45 \times 90 \times 8 \mathrm{~cm}$; OysterGro) and suspended at depths of $1.0-4.5 \mathrm{~m}$ at vertical intervals of $0.5 \mathrm{~m}$. Survival was then measured for another month in reoxygenated water.

\section{Statistics}

All data are presented as the mean \pm standard on (SD). Data were analyzed using the independent sample $t$-test or 1-way analysis of variance followed by Duncan's test.

\section{RESULTS AND DISCUSSION}

\section{Nature of hypoxia}

We began monitoring the oysters and ambient environmental conditions at each site as soon as possible after establishing the study sites; hypoxia appeared to have begun 3-5 d earlier. Therefore, for the missing data, we relied on local government datasets obtained from routine monitoring of oysters and ambient water. Based on these data and our measurements, the 2 bays initially showed drastic oxygen depletion from the bottom of the water column for 4-5 d, after which it shortly stabilized with the formation of a pelagic oxycline.

The oxyclines were thin but robust, at depths of 2-4 $\mathrm{m}$ at HS-1 and 2-5 m at HS-2, with respective thicknesses of 2 and $3 \mathrm{~m}$. This resulted in the formation of 3 oxygen layers: the upper normoxic layer (DO $>4 \mathrm{mg} \mathrm{l}^{-1}$ ), middle oxycline (DO $<1-4 \mathrm{mg} \mathrm{l}^{-1}$ ), and bottom anoxic layer (DO $<1 \mathrm{mg} \mathrm{l}^{-1}$ ) (Fig. 2). DO gradients at both HS sites were the most drastic of those ever measured in or near the study area (Choi et al. 2009, Kim et al. 2012). Comparing the vertical DO profiles, the HS-1 oxycline was narrower and shallower than that of HS-2, and the HS-1 normoxic layer was closer to the anoxic layer. 

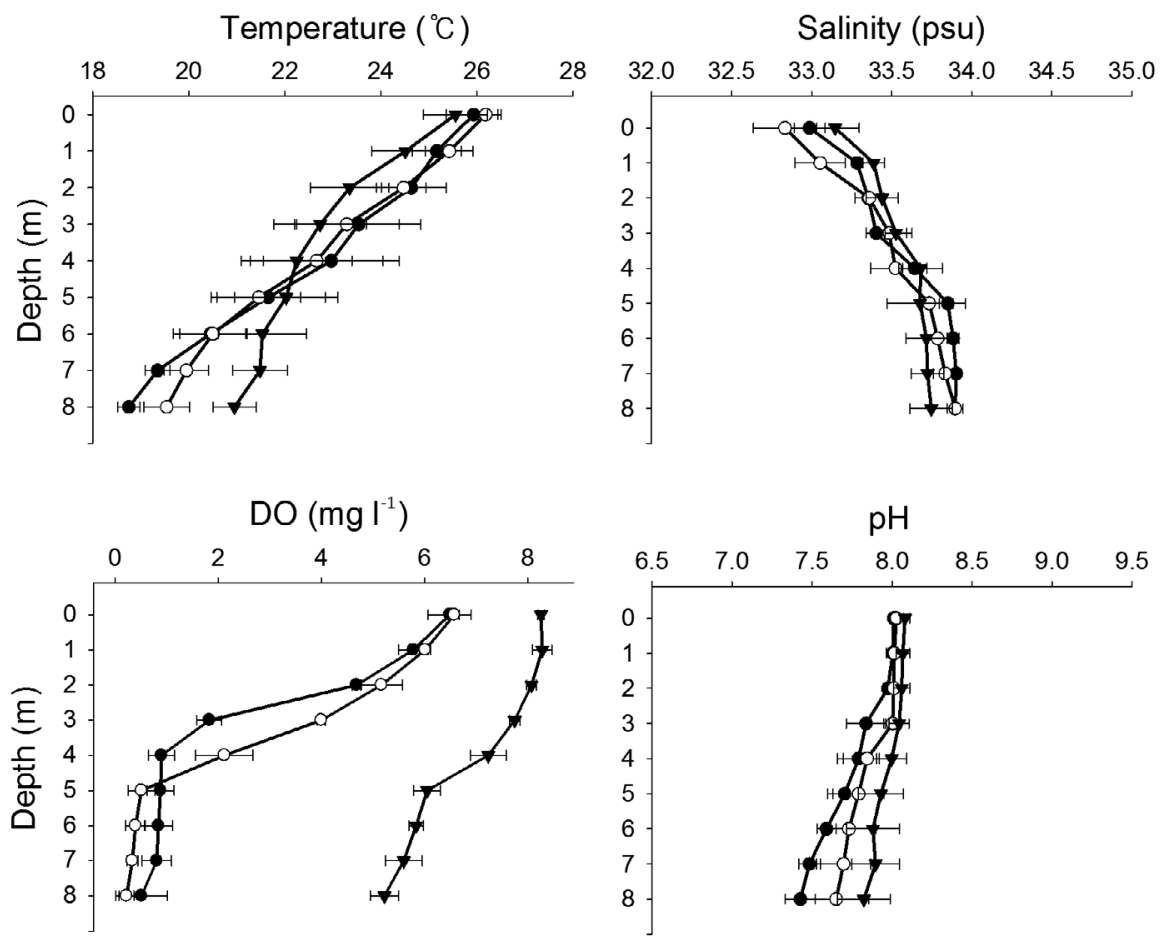

Fig. 2. Vertical profiles of the major environmental variables examined at the study sites during oxycline persistence. Solid circle: hypoxic site 1 (HS-1); empty circle: hypoxic site 2 (HS-2); solid triangle: reference site (RS). Data are means \pm SD

in our study. However, in general, temperature-driven vertical stability is likely when the mixing forces of wind and wave action are minimal, which are realistic conditions in highly sheltered bodies of water. Therefore, the density differential generated by the temperature change in these highly sheltered bays appeared to be strong enough to establish an oxycline, even though we could not identify it.

Table 3 exhibits phytoplankton and protozoan composition during oxycline persistence. The hypoxic sites had simple phytoplankton compositions. Three diatoms (Chaetoceros curvicetus, C. didymus, and $C$. affinis) and unidentified protozoans dominated the hypoxic sites. The sites were also characterized by the occurrence of Akashiwo sanguinea (density: 5-20 cells $\mathrm{ml}^{-1}$; data not shown), a mucusproducing dinoflagellate used as an indicator of changes in temper-

In general, during the progression of coastal hypoxia, bottom eutrophication proceeds as a result of microbial growth and respiration, producing a high demand for oxygen which results in the formation of a pelagic oxycline under a stratified water column (Diaz \& Rosenberg 2008, O'Boyle \& Nolan 2010). In our study, the 2 sites were characterized by high levels of COD at the surface and nutrients $\left(\mathrm{NH}_{4}-\mathrm{N}\right.$, $\mathrm{NO}_{2}-\mathrm{N}, \mathrm{NO}_{3}-\mathrm{N}, \mathrm{DIN}$, and $\mathrm{PO}_{4}-\mathrm{P}$ ) from decomposed matter at the bottom (Table 2). We interpreted this environmental configuration to indicate that oxygendepleting microbial decomposition might have progressed upwards to a certain depth where the density differential was sufficient to form a pelagic oxycline. This pattern is common in coastal oxyclines (Diaz \& Rosenberg 2008).

Density differentials between 2 water layers frequently arise from differences in salinity, temperature, or a combination of both (Lin et al. 2006, Kim et al. 2012). Our study sites exhibited apparent vertical changes in temperature and salinity, with more significant changes in temperature (Fig. 2). There were differences of $6-7^{\circ} \mathrm{C}$ over the $8 \mathrm{~m}$ depth of the water column, without any one layer showing a sharp change indicative of a thermocline. The mechanism explaining the formation of a pelagic oxycline without an apparent thermocline remained unidentified ature and salinity (Matsubara et al. 2007, Badylak et al. 2014) and a representative species of red tides in Korea (Park et al. 2013). The reference site contained a greater diversity of species, such as C. curvicetus, Chaetoceros debilis, and Pseudo-nitzschia spp. Few unidentified protozoans and $A$. sanguinea were observed. The representative shellfish-killing dinoflagellates in or near Korean waters, Karenia mikimotoi and Heterocapsa circularisquama (Horiguchi 1995, Basti et al. 2011, Brand et al. 2012), were not found in our study. The phytoplankton composition offered insight into the environmental status before the occurrence of bottom eutrophication at the study sites.

\section{Damage to farmed oysters}

We identified the health status of the farmed oysters before hypoxia; Table 1 summarizes the longline system and oyster growth performance before hypoxia at the study sites. The test oysters were from wild seeds overwintered in an intertidal zone for hardening. Lines carrying seeds of approximately $50 \mathrm{~mm}$ in shell length were suspended in April or May. The oysters were approximately $70 \mathrm{~mm}$ in shell length, with $70 \%$ survival by the end of July, 7-10 d 
Table 2. Mean $( \pm \mathrm{SD})$ changes in organic and inorganic variables during the oxycline and after its disappearance at the study sites. For each variable, the upper row are the values at $1 \mathrm{~m}$ depth and the lower row are values at the bottom. Chl $a$ values are at a depth of $1 \mathrm{~m}$. HS-1: hypoxic site $1_{;}$HS-2: hypoxic site 2; RS: reference site; COD: chemical oxygen demand; $\mathrm{NH}_{4}-\mathrm{N}_{\text {, }}$ $\mathrm{NO}_{2}-\mathrm{N}, \mathrm{NO}_{3}-\mathrm{N}$ : ammonium, nitrit, and nitrate nitrogen; DIN: dissolved inorganic nitrogen; chl a: chlorophyll a

\begin{tabular}{|c|c|c|c|c|c|c|}
\hline \multirow{2}{*}{ Variable } & \multicolumn{3}{|c|}{ - During oxycline } & & \multirow{2}{*}{$\begin{array}{c}\text { After oxycline } \\
\text { HS-2 }\end{array}$} & \multirow[b]{2}{*}{$\mathrm{RS}$} \\
\hline & HS-1 & HS-2 & $\mathrm{RS}$ & HS-1 & & \\
\hline $\mathrm{COD}\left(\mathrm{mg} \mathrm{l}^{-1}\right)$ & $\begin{array}{l}4.12 \pm 0.82 \\
2.73 \pm 0.51\end{array}$ & $\begin{array}{l}4.63 \pm 0.34 \\
2.73 \pm 0.22\end{array}$ & $\begin{array}{l}3.25 \pm 0.54 \\
1.06 \pm 0.31\end{array}$ & $\begin{array}{l}2.42 \pm 0.21 \\
3.01 \pm 0.23\end{array}$ & $\begin{array}{l}3.33 \pm 0.17 \\
3.52 \pm 0.35\end{array}$ & $\begin{array}{l}1.14 \pm 0.24 \\
1.32 \pm 0.15\end{array}$ \\
\hline $\mathrm{NH}_{4}-\mathrm{N}\left(\mathrm{mg} \mathrm{l}^{-1}\right)$ & $\begin{array}{l}0.018 \pm 0.003 \\
0.299 \pm 0.042\end{array}$ & $\begin{array}{l}0.038 \pm 0.004 \\
0.332 \pm 0.065\end{array}$ & $\begin{array}{l}0.009 \pm 0.001 \\
0.117 \pm 0.022\end{array}$ & $\begin{array}{l}0.025 \pm 0.007 \\
0.025 \pm 0.009\end{array}$ & $\begin{array}{l}0.017 \pm 0.005 \\
0.028 \pm 0.009\end{array}$ & $\begin{array}{l}0.004 \pm 0.000 \\
0.014 \pm 0.002\end{array}$ \\
\hline $\mathrm{NO}_{2}-\mathrm{N}\left(\mathrm{mg} \mathrm{l}^{-1}\right)$ & $\begin{array}{l}0.002 \pm 0.000 \\
0.002 \pm 0.000\end{array}$ & $\begin{array}{l}0.005 \pm 0.001 \\
0.006 \pm 0.001\end{array}$ & $\begin{array}{l}0.001 \pm 0.000 \\
0.005 \pm 0.000\end{array}$ & $\begin{array}{l}0.008 \pm 0.001 \\
0.007 \pm 0.002\end{array}$ & $\begin{array}{l}0.004 \pm 0.001 \\
0.012 \pm 0.001\end{array}$ & $\begin{array}{l}0.002 \pm 0.000 \\
0.005 \pm 0.001\end{array}$ \\
\hline $\mathrm{NO}_{3}-\mathrm{N}\left(\mathrm{mg} \mathrm{l}^{-1}\right)$ & $\begin{array}{l}0.048 \pm 0.011 \\
0.075 \pm 0.012\end{array}$ & $\begin{array}{l}0.049 \pm 0.007 \\
0.078 \pm 0.007\end{array}$ & $\begin{array}{l}0.001 \pm 0.000 \\
0.025 \pm 0.008\end{array}$ & $\begin{array}{l}0.014 \pm 0.003 \\
0.012 \pm 0.003\end{array}$ & $\begin{array}{c}0.017 \pm 0.004 \\
0.025 \pm 0.0 .2\end{array}$ & $\begin{array}{l}0.009 \pm 0.000 \\
0.016 \pm 0.004\end{array}$ \\
\hline $\operatorname{DIN}\left(\mathrm{mg} \mathrm{l}^{-1}\right)$ & $\begin{array}{l}0.068 \pm 0.011 \\
0.376 \pm 0.011\end{array}$ & $\begin{array}{l}0.092 \pm 0.011 \\
0.415 \pm 0.028\end{array}$ & $\begin{array}{l}0.070 \pm 0.005 \\
0.174 \pm 0.054\end{array}$ & $\begin{array}{l}0.047 \pm 0.005 \\
0.045 \pm 0.009\end{array}$ & $\begin{array}{l}0.037 \pm 0.017 \\
0.055 \pm 0.011\end{array}$ & $\begin{array}{l}0.140 \pm 0.022 \\
0.100 \pm 0.023\end{array}$ \\
\hline $\mathrm{PO}_{4}-\mathrm{P}\left(\mathrm{mg} \mathrm{l}^{-1}\right)$ & $\begin{array}{l}0.003 \pm 0.000 \\
0.021 \pm 0.004\end{array}$ & $\begin{array}{l}0.003 \pm 0.001 \\
0.026 \pm 0.003\end{array}$ & $\begin{array}{l}0.001 \pm 0.000 \\
0.007 \pm 0.002\end{array}$ & $\begin{array}{l}0.014 \pm 0.004 \\
0.015 \pm 0.004\end{array}$ & $\begin{array}{l}0.015 \pm 0.002 \\
0.014 \pm 0.002\end{array}$ & $\begin{array}{l}0.006 \pm 0.001 \\
0.011 \pm 0.003\end{array}$ \\
\hline Chl a $\left(\mu g l^{-1}\right)$ & $8.36 \pm 1.45$ & $10.12 \pm 2.75$ & $6.54 \pm 1.21$ & $9.47 \pm 1.35$ & $11.88 \pm 0.32$ & $4.61 \pm 0.21$ \\
\hline
\end{tabular}

before the hypoxia event began. The culture system was standard, and the quality of the oysters in the system was normal or even better than average (NFRDI 2012), suggesting that the oysters were healthy enough to provide useful data for the study.

The oxycline lasted almost 1 mo and resulted in high oyster mortality. Mortality was oxycline-depth dependent (Table 4). Both oxyclines (at Sites HS-1 and HS-2) started at a depth of $2 \mathrm{~m}$ but ended at different depths; $4 \mathrm{~m}$ for the former and $5 \mathrm{~m}$ for the

Table 3. Phytoplankton and protozoan composition during the oxycline persistence. HS-1: hypoxic site 1 ; HS-2: hypoxic site 2 ; RS: reference site. (+++) frequency $>50 \%$; (++) frequency $>5 \%$; (+) frequency $<5 \%$; (-) not found

\begin{tabular}{|lccc|}
\hline Species & \multicolumn{3}{c|}{ Dominance } \\
& HS-1 & HS-2 & RS \\
\hline Harmless species & & & \\
Chaetoceros curvicetus & ++ & ++ & ++ \\
C. didymus & ++ & ++ & - \\
C. affinis & ++ & ++ & - \\
C. debilis & + & + & ++ \\
Pseudo-nitzschia spp. & - & - & ++ \\
Akashiwo sanguinea & ++ & ++ & + \\
Leptocylindrus spp. & - & + & + \\
Skeletonema costatum & + & + & + \\
Ceratium spp. & - & + & + \\
Others & + & + & ++ \\
Unidentified protozoans & +++ & +++ & + \\
Shellfish-killing species & & & \\
Karenia mikimotoi & - & - & - \\
Heterocapsa circularisquama & - & - & - \\
\hline
\end{tabular}

latter. The difference in the end depth resulted in different mortality profiles according to depth. For example, the DO concentration at a depth of $2 \mathrm{~m}$ was similar at both sites $\left(4.68 \pm 0.09 \mathrm{mg} \mathrm{l}^{-1}\right.$ for HS-1, $5.17 \pm 0.41 \mathrm{mg} \mathrm{l}^{-1}$ for HS-2); however, mortality at lower depths differed significantly $(57.7 \pm 6.4 \%$ for HS- $1,37.0 \pm 7.2 \%$ for HS- 2 ; $<0.05)$. This trend continued at a depth of $3 \mathrm{~m}(88.9 \pm 2.1 \%$ for HS- $1,61.7 \pm$ $11.3 \%$ for HS-2), where DO was $1.83 \pm 0.24 \mathrm{mg} \mathrm{l}^{-1}$ for HS-1 and $4.00 \pm 0.08 \mathrm{mg} \mathrm{l}^{-1}$ for HS-2. Complete mortality was observed at and below $4 \mathrm{~m}$ at both sites, even though the DO level at $4 \mathrm{~m}$ in HS-2 was $2.12 \pm$ $0.56 \mathrm{mg} \mathrm{l}^{-1}$. Surprisingly, there was considerable mortality of oysters above the oxycline, where DO was near or above $5 \mathrm{mg} \mathrm{l}^{-1}$.

Oysters are considered less sensitive to oxygen deprivation because of their minimal physiological oxygen requirements (Widdows et al. 1989, Wang \& Widdows 1991, Hand \& Hardewig 1996, Guppy \& Withers 1999). However, numerous studies provide evidence contradicting this low oxygen resistance (Hochachka 1997, Wu 2002, Brouwer et al. 2007, G. Han et al. 2013, J. Han et al. 2013, Jeppesen et al. 2016). Diaz \& Rosenberg (1995) suggested a threshold level of $2 \mathrm{mg} \mathrm{l}^{-1}$, although this level has been debated by Gray et al. (2002), Vaquer-Sunyer \& Duarte (2008), and Steckbauer et al. (2011), who demonstrated onsets of hypoxic mortality at higher DO concentrations. In this study, oyster mortality at higher DO levels might be explained by the combined effects of other variables, although none of the suspected variables appeared to be extreme enough to exacerbate oyster 
mortality; however, we did not measure the effects of these variables directly. Instead, our findings were suggestive of direct damage by toxic compounds from the bottom layer that penetrated the oxycline and overshadowed the effects of the other variables. One candidate toxic compound was hydrogen sulfide, a highly toxic product of anaerobic decomposition under anoxic conditions (Henrichs \& Reeburgh 1987, Diaz \& Rosenberg 1995, Jahn \& Theede 1997, Hargrave et al. 2008). Our finding of higher mortality at HS-1 and greater toxicity at depths closer to the anoxic conditions supported this assumption.

\section{Damage persistence after reoxygenation}

During early September, DO and other variables returned to near-normal levels (Fig. 3, Table 2). Oysters that had survived in the upper normoxic waters were caged and suspended at a depth of $4.5 \mathrm{~m}$ for another month. Table 5 summarizes their survival. The oysters exhibited significant mortality compared with those from the reference site $(\mathrm{p}<$ 0.05). Unlike in the hypoxic water, mortality was not depthdependent, suggesting that it was caused by the earlier hypoxic conditions

Comparing post-hypoxia survival rates of the surviving oysters between the 2 sites, oysters at HS-2 exhibited better survival than did those at HS-1. There were both significant $(p<0.05)$ and marginal $(p>0.05)$ differences in the environmental variables between the 2 sites (Fig. 3). However, these differences were not sufficient to induce mortality, as the variables were within the normal ranges for oysters $(\mathrm{MOF}$ 2001). This finding supported the hypothesis that the higher mortal- ity at HS-1 was due to greater damage caused by the earlier hypoxic conditions rather than current environmental variables in the normoxic waters.

\section{CONCLUSIONS}

The establishment of a pelagic oxycline in the oyster longline area provided a natural laboratory with a realistic experimental design to study the nature of hypoxia in sheltered shallow coastal waters and its damage potential to oysters. During the summer of 2013, a pelagic oxycline was estab-
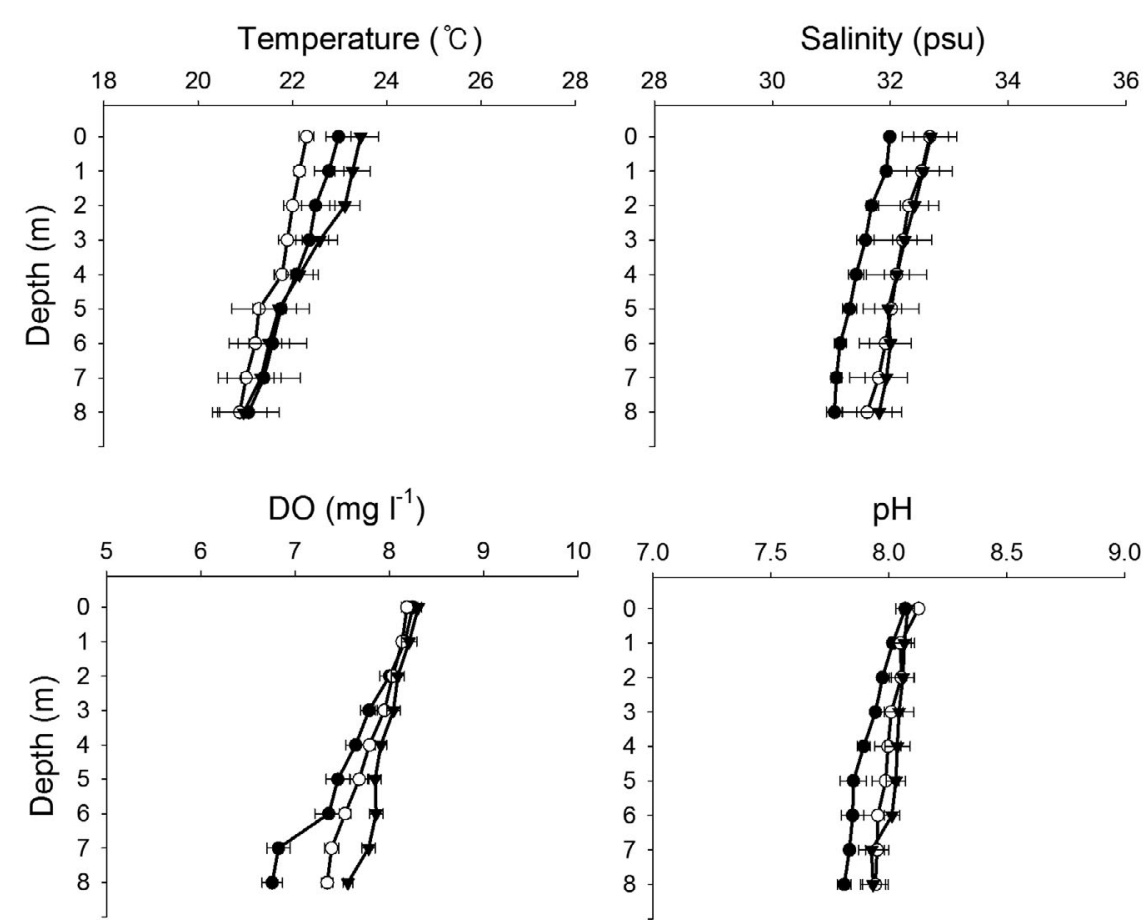

Fig. 3. Vertical profiles of the major environmental variables at the study sites after the oxycline. Solid circles: hypoxic site 1 (HS-1); empty circles: hypoxic site 2 (HS-2); solid triangles: reference site (RS). Data are means \pm SD 
Table 5. Mean ( \pm SD) depth-dependent percentage survival of Crassostrea gigas in reoxygenated water. HS-1: hypoxic site 1; HS-2: hypoxic site 2; RS: reference site

\begin{tabular}{|c|c|c|c|c|c|c|c|c|c|}
\hline \multirow[t]{2}{*}{ Site } & \multicolumn{9}{|c|}{-Oyster bag position by depth (m) } \\
\hline & Average & 1.0 & 1.5 & 2.0 & 2.5 & 3.0 & 3.5 & 4.0 & 4.5 \\
\hline HS-1 & 53.7 & $86.6 \pm 5.8$ & $78.0 \pm 7.3$ & $67.1 \pm 3.9$ & $32.3 \pm 6.0$ & $45.9 \pm 7.4$ & $47.4 \pm 9.4$ & $35.3 \pm 4.9$ & $37.1 \pm 6.0$ \\
\hline HS-2 & 79.9 & $87.2 \pm 7.3$ & $86.5 \pm 5.2$ & $85.3 \pm 3.6$ & $88.1 \pm 5.2$ & $78.0 \pm 9.3$ & $83.5 \pm 6.8$ & $65.2 \pm 6.1$ & $65.4 \pm 8.7$ \\
\hline $\mathrm{RS}$ & 93.9 & $94.4 \pm 2.7$ & $98.5 \pm 3.0$ & $92.8 \pm 2.1$ & $95.7 \pm 3.4$ & $93.4 \pm 2.9$ & $87.0 \pm 4.1$ & $92.8 \pm 2.5$ & $96.6 \pm 2.1$ \\
\hline
\end{tabular}

lished in 2 semi-enclosed shallow bays (sites HS-1 and HS-2), where Crassostrea gigas were suspended in longline systems. The oxycline appeared to have formed following a predictable pathway, in which DO depletion was first initiated by microbial decomposition of organic matter at the bottom, leading to hypoxia, which rapidly expanded upwards for a number of days until becoming blocked by a temperature-driven gradual density differential without an apparent thermocline. The 2 hypoxic sites differed in oxycline profile: the oxycline at HS-1 was shallower and narrower than that at HS-2. The water above the oxycline was normoxic (DO $>4 \mathrm{mg}$ $\mathrm{l}^{-1}$ ), while that below the oxycline was anoxic ( $\mathrm{DO}<$ $1 \mathrm{mg} \mathrm{l}^{-1}$ ) at both sites. The oxyclines accompanied significant changes $(p<0.05)$ in other variables such as temperature, $\mathrm{pH}$, salinity, COD, levels of $\mathrm{NH}_{4}-\mathrm{N}, \mathrm{NO}_{2}-\mathrm{N}, \mathrm{NO}_{3}-\mathrm{N}, \mathrm{DIN}$, and $\mathrm{PO}_{4}-\mathrm{P}$, and phytoplankton composition; however, these changes were not drastic enough to be fatal to oysters. The oxyclines, which lasted almost a month, caused high mortality in the oysters in a DO-dependent manner. Interestingly, a considerable number of oysters above the oxyclines ( $\mathrm{DO}>4 \mathrm{mg} \mathrm{l}^{-1}$ ) died in a depthdependent way, suggestive of the presence of undetermined toxic compounds, which possibly overshadowed the effects of DO and/or synergized with other variables in the upper water to exert detrimental effects. The elevated mortality of the oysters near the oxycline was likely driven by the presence and upward dispersion of toxic matter from the environment below the oxycline, which was supported by the higher mortality rates at HS-1. The oysters continued to die after complete breakdown of the hypoxic event, probably due to damage caused by the earlier hypoxic conditions. The results in this study offer insights into hypoxia in sheltered shallow coastal areas and site selection for oyster longline aquaculture systems. Moreover, they can be used to guide site selection for oyster longline aquaculture systems, as oxycline-associated toxicity may be enhanced in highly sheltered shallow waters.
Acknowledgements. The study was supported by Basic Research Funds of the National Institute of Fisheries Science (NIFS) (R2017048), Korea. The authors are highly appreciative of the NIFS research assistants and research vessel crews, not listed in this paper, for their efforts in assisting with the labor during the fieldwork. The authors also thank the 2 local governments of Tongyeong City and Goseong County for providing the oyster aquaculture and environmental data collected prior to the hypoxic event at our study sites.

\section{LITERATURE CITED}

Altieri AH, Gedan KB (2015) Climate change and dead zones. Glob Change Biol 21:1395-1406

Badylak S, Phylips EJ, Mathews AL (2014) Akashiwo sanguinea (Dinophyceae) blooms in a sub-tropical estuary: an alga for all seasons. Plankton Benthos Res 9:147-155

Basti L, Go J, Higuchi K, Nagai K, Segawa S (2011) Effects of the toxic dinoflagellate Heterocapsa circularisquama on larvae of the pearl oyster Pinctada fucata martensii (Dunker, 1873). J Shellfish Res 30:177-186

Brand LE, Campbell L, Bresnan E (2012) Karenia: the biology and ecology of a toxic genus. Harmful Algae 14: 156-178

Breitburg D (2002) Effects of hypoxia and the balance between hypoxia and enrichment on coastal fishes and fisheries. Estuaries 25:767-781

Brouwer M, Brown Peterson NJ, Larkin P, Patel V, Denslow N, Manning S, Hoexum BT (2007) Molecular and whole animal responses of grass shrimp, Palaemonetes pugio, exposed to chronic hypoxia. J Exp Mar Biol Ecol 341: 16-31

Cancino J, Gallardo J, Torres F (2003) Combined effects of dissolved oxygen concentration and water temperature on embryonic development and larval shell secretion in the marine snail Chorus giganteus (Gastropoda: Muricidae). Mar Biol 142:133-139

Choi WJ, Kim SS, Choi OI, Kim SK, Shim JH (2009) Hypoxia in the Korean coastal waters. National Fisheries Research and Development Institute, GMK Communication Publishing, Busan (in Korean)

Diaz RJ, Rosenberg R (1995) Marine benthic hypoxia: a review of its ecological effects and the behavioral responses of benthic macrofauna. Oceanogr Mar Biol Annu Rev 33:245-303

*Diaz RJ, Rosenberg R (2008) Spreading dead zones and consequences for marine ecosystems. Science 321:926-929

Ekau W, Auel H, Pörtner HO, Gilbert D (2010) Impacts of hypoxia on the structure and processes in pelagic communities (zooplankton, macro-invertebrates and fish). Biogeosciences 7:1669-1699 
Gobler CJ, DePasquale EL, Griffith AW, Baumann H (2014) Hypoxia and acidification have additive and synergistic negative effects on the growth, survival and metamorphosis of early life stage bivalves. PLOS ONE 9:e83648

Grasshoff K, Kremling K, Ehrhardt M (1999) Methods of seawater analysis. Wiley-VCH, Weinheim

Gray JS, Wu RSS, Or YY (2002) Effects of hypoxia and organic enrichment on the coastal marine environment. Mar Ecol Prog Ser 238:249-279

Guppy M, Withers P (1999) Metabolic depression in animals: physiological perspectives and biochemical generalizations. Biol Rev Camb Philos Soc 74:1-40

Han GD, Zhang S, Marshall DJ, Ke C, Dong Y (2013) Metabolic energy sensors (AMPK and SIRT1), protein carbonylation and cardiac failure as biomarkers of thermal stress in an intertidal limpet: linking energetic allocation with environmental temperature during aerial emersion. J Exp Biol 216:3273-3282

Han JC, Jo Q, Park YC, Park TG, Lee DC, Cho KC (2013) A report on the mass summer mortalities of the farmed Pacific oysters, Crassostrea gigas and bay scallops Argopecten irradians in the local waters of Goseong Bay, Korea. Korean J Malacol 29:239-244

Hand SC, Hardewig I (1996) Downregulation of cellular metabolism during environmental stress: mechanisms and implications. Annu Rev Physiol 58:539-563

Hargrave BT, Holmer M, Newcombe CP (2008) Towards a classification of organic enrichment in marine sediments based on biochemical indicators. Mar Pollut Bull 56: 810-824

Henrichs SM, Reeburgh WS (1987) Anaerobic mineralization of marine sediment organic matter: rates and the role of anaerobic processes in the oceanic carbon economy. Geomicrobiol J 5:191-237

Hochachka PW (1997) Oxygen-a key regulatory metabolite in metabolic defense against hypoxia. Am Zool 37: 595-603

Horiguchi T (1995) Heterocapsa circularisquama sp. nov. (Peridiniales, Dinophyceae): a new marine dinoflagellate causing mass mortality of bivalves in Japan. Phycol Res 43:129-136

Jahn A, Theede H (1997) Different degrees of tolerance to hydrogen sulphide in populations of Macoma balthica (Bivalvia, Tellinidae). Mar Ecol Prog Ser 154:185-196

Jeppesen R, Rodriguez M, Rinde J, Haskins J, Hughes B, Mehner L, Wasson K (2016) Effects of hypoxia on fish survival and oyster growth in a highly eutrophic estuary. Estuaries Coasts, doi:10.1007/s12237-016-0169-y (in press)

Keeling RF, Körtzinger A, Gruber N (2010) Ocean deoxygenation in a warming world. Annu Rev Mar Sci 2:199-229

Khan B, Ringwood AH (2016) Cellular biomarker responses to hypoxia in eastern oysters and Atlantic ribbed marsh mussels. Mar Ecol Prog Ser 546:123-133

Kim SY, Lee YH, Kim YS, Shim HJ and others (2012) Characteristics of marine environmental in the hypoxic sea-

Editorial responsibility: Gianluca Sará,

Palermo, Italy son at Jinhae Bay in 2010. Korean J Nat Conserv 6: 115-129 (in Korean with English Abstract)

*Lin J, Xie L, Pietrafesa LJ, Shen J, Mallin MA, Durako MJ (2006) Dissolved oxygen stratification in two micro-tidal partially-mixed estuaries. Estuar Coast Shelf Sci 70: 423-437

*Matsubara T, Nagasoe S, Yamasaki Y, Shikata T, Shimasaki Y, Oshima Y, Honjo T (2007) Effects of temperature, salinity and irradiance on the growth of the dinoflagellate Akashiwo sanguinea. J Exp Mar Biol Ecol 342: 226-230

MOF (Ministry of Oceans and Fisheries) (2001) Development of optimum technology for sustainable production of shellfish. Ministry of Oceans and Fisheries, Seoul (in Korean)

MOLIT (Ministry of Land, Infrastructure and Transport) (2010) Standard methods for the examination of environment pollution. MOLIT, Seoul (in Korean)

NFRDI (National Fisheries Research and Development Institute) (2012) Standard manual for the pacific oyster hanging culture. National Fisheries Research and Development Institute, Busan (in Korean)

O'Boyle S, Nolan G (2010) The influence of water column stratification on dissolved oxygen levels in coastal and shelf waters around Ireland. Biol Environ 110:195-209

Park TG, Lim WA, Park YT, Lee CK, Jeong HJ (2013) Economic impact, management and mitigation of red tides in Korea. Harmful Algae 30S:S131-S143

Steckbauer AC, Duarte M, Carstensen J, Vaquer-Sunyer R, Conley DJ (2011) Ecosystem impacts of hypoxia: thresholds of hypoxia and pathways to recovery. Environ Res Lett 6:025003

Stickle WB, Kapper MA, Liu LL, Gnaiger E, Wang SY (1989) Metabolic adaptations of several species of crustaceans and molluscs to hypoxia: tolerance and microcalorimetric studies. Biol Bull (Woods Hole) 177:303-312

Strickland JDH, Parsons TR (1972) A practical handbook of seawater analysis. Bulletin 167, Fisheries Research Board of Canada, Ottawa

Vaquer-Sunyer R, Duarte CM (2008) Thresholds of hypoxia for marine biodiversity. Proc Natl Acad Sci USA 105: 15452-15457

*Wang WX, Widdows J (1991) Physiological responses of mussel larvae Mytilus edulis to environmental hypoxia and anoxia. Mar Ecol Prog Ser 70:223-236

*Wang Y, Hu M, Wong WH, Paul KSS, Cheung SG (2011) The combined effects of oxygen availability and salinity on physiological responses and scope for growth in the green-lipped mussel Perna viridis. Mar Pollut Bull 63: 255-261

Widdows J, Newell NIE, Maon R (1989) Effects of hypoxia and anoxia on survival, energy metabolism and feeding of oyster larvae (Crassostrea virginica, Gmelin). Biol Bull (Woods Hole) 177:154-166

WWu RSS (2002) Hypoxia: from molecular responses to ecosystem responses. Mar Pollut Bull 45:35-45

Submitted: April 12, 2017; Accepted: October 1, 2017

Proofs received from author(s): November 9, 2017 